\title{
Biosynthetic Targeting Pathway of Lysosomal Membrane Glycoproteins
}

\author{
リソソーム膜糖タンパク質の生合成送達経路
}

\author{
Nabi, I.R. \\ Département de pathologie, Université de Montréal, Montréal, Québec, Canada H3C 3J7, FAX: 1-514-343-5755
}

\begin{abstract}
Key Words: lysosomal glycoproteins, sorting signals, targeting pathways, endocytosis
\end{abstract}
\begin{abstract}
A number of lysosomal glycoproteins exist which are membrane associated and do not contain the mannose-6-phosphate lysosomal targeting signal which sorts soluble lysosomal hydrolases to the lysosome in the Golgi apparatus. These include lysosomal acid phosphatase (LAP), which is targeted as a transmembrane protein to the lysosome where it is cleaved to release the soluble enzyme, and a number of lysosomal membrane associated glycoproteins including the homologous families of LAMP-1 and LAMP-2 as well as other smaller molecular weight glycoproteins including LIMP II and CD63. The cytoplasmic domain of LAP, LAMP-1 and LIMP II is capable of targeting the ectodomain of non-lysosomal glycopoteins to the lysosome. Except for LIMP II, the lysosomal membrane glycoproteins contain a Gly-Tyr-X-X-hydrophobic amino acid lysosomal targeting motif in their cytoplasmic domains. Studies of LAP, LAMP-1 and LAMP-2 have generated conflicting data as to the biosynthetic targeting pathway of these proteins and, in particular, as to whether it includes the plasma membrane.
\end{abstract}

\section{A. Introduction}

One of the first cellular targeting signals identified was the M6P responsible for the intracellular sorting of soluble lysosomal hydrolases to the lysosome. Mannose-6-phosphate (M6P) containing proteins interact with a M6P receptor of 46 or $200 \mathrm{kDa}$ in the trans-Golgi and are then directed to a prelysosomal compartment where they dissociate from the M6P receptor and are transported to the lysosome defining an intracellular lysosomal targeting pathway (1-3). A number of lysosomal proteins exist which do not contain M6P residues and yet are efficiently transported to the lysosome.

\section{B. Lysosomal Proteins Which Lack the M6P Targeting Sig- nal}

The lysosomal proteins which do not contain M6P residues are lysosomal acid phosphatase (LAP) and a number of integral membrane lysosomal glycoproteins. Lysosomal acid phosphatase is synthesized as a transmembrane protein with 7$8 \mathrm{~N}$-linked oligosaccharide chains, a single transmembrane domain and an 18 amino acid cytoplasmic tail; upon arrival to the lysosome it is proteolytically cleaved to release the soluble en-
要 約

可溶性のリソソーム加水分解酵素をリソソームへ選別する リソソーム送達シグナルであるマンノース-6-リン酸を持たず、 かつ、膜結合性である多くのリソソーム糖タンパク質がゴルジ 体に存在する。その一つであるリソソーム酸性ホスファターゼ (LAP)は、リソソームへ膜貫通タンパク質として送達され、そ こで開裂し可溶な酵素を遊離する。また、LIMP IIPCD63など の他の低分子量糖タンパク質や、LAMP-1、LAMP-2の相同ファ ミリーを含む多くのリソソーム膜結合性タンパク質も、それら の一つである。LAP、LAMP-1そしてLIMP IIの細胞質ドメイン は、非リソソーム糖タンパク質の細胞外ドメインをリソソーム へ送達できる。LIMP IIを除きリソソーム膜糖タンパク質は、そ の細胞質ドメインに、グリシン-チロシン-X-X-疎水性アミノ酸 残基からなるリソソーム送達モチーフを含む。LAP、LAMP1、LAMP-2の研究は、これらのタンパク質の生合成送達経路に 関し、また、特にそれに細胞膜が関わるのかどうかといった問 題に矛盾した結果をもたらした。

A. はじめに

初めに同定された細胞内送達シグナルの一つは、リソソー ムへ可溶なリソソーム加水分解酵素の選別を行う M6P(M6P) だった。M6Pを含むタンパク質は、トランスゴルジの $46 \mathrm{kDa}$ るいは200 kDaのM6レセプターと結合し、その後プレリソソー ム小胞へ誘導されM6レセプターから遊離し、そして、リソソー ムへ輸送され、細胞内リソソーム送達経路を形成している(13)。一方、M6P残基を含まないにもかかわらず、効果的にリソ ソームへ輸送される多くのリソソームタンパク質が存在する。

B. M6P送達 シグナルを欠くリソソームタンパク質 リソソーム酸性ホスファターゼ(LAP)や、多くのリソソー ム膜貫通タンパク質には、マンノース-6-リン酸(M6P)残基が存 在しない。LAPは、7-8個のN-結合オリゴ糖鎖を持ち、1本の膜 貫通ドメインと18アミノ酸残基の細胞質内テイルからなる膜貫 通タンパク質として合成され、リソソームへ到達し加水分解に より開裂し可溶な酵素を遊離する(4-7)。リソソームの主な糖夕 
zyme (4-7). The major glycoproteins of the lysosome are a class of heavily glycosylated transmembrane proteins of 100 $120 \mathrm{kDa}$ referred to alternately as LAMPs (lysosome associated membrane proteins), lgps (lysosomal glycoproteins), LEP (lysosome, endosome protein) or LIMP III (lysosomal integral membrane protein) [reviewed in $(2,8)]$. The two classes of LAMPs, encompassing the homologous families of LAMP-1 and LAMP-2, exhibit approximately $20 \%$ amino acid homology and similar structural features including a short cytoplasmic tail of 11 amino acids, a transmembrane domain and an ectodomain consisting of two internally homologous domains separated by a proline rich hinge region. The similarities between LAMP-1 and LAMP-2 are reflected in the conservation of all the cysteine residues of the two proteins, a majority of the 15-18 N-linked glycosylation sites and the presence of a conserved glycine-tyrosine motif in the short cytoplasmic domain (9-18). Other lower molecular weight lysosomal proteins have also been identified $(19,20)$. LIMP II $(74 \mathrm{kDa})$ and lgp85 exhibit sequence identity and contain a short $\mathrm{N}$-terminal cytoplasmic tail and a large luminal domain containing an uncleaved signal peptide and two hydrophobic domains near its carboxy terminal which may serve to anchor the protein to the membrane; interestingly, the luminal domain exhibits homology to the plasma membrane cell adhesion protein $\operatorname{CD} 36(21$, 22). CD63 contains 4 hydrophobic regions, three $N$-linked glycosylation sites and a short cytoplasmic domain containing a Gly-Tyr motif; interestingly, this lysosomal protein exhibits complete sequence homology to a melanoma cell surface antigen, ME491 (23, 24).

\section{Lysosomal Sorting Signals besides M6P}

In spite of their extensive glycosylation, these various lysosomal membrane proteins do not contain the M6P residue which sorts soluble lysosomal hydrolases in the TGN to the lysosome $(5,17,20,25,26)$. LAMP-1, LAMP-2 and LIMP-II are transmembrane proteins while LAP is synthesized as a transmembrane protein and only upon arrival to the lysosome is it proteolytically cleaved to release the soluble enzyme. Generation of chimeric proteins has shown that the cytoplasmic domain of LAP, LEP100 (avian LAMP-1) and LIMP II is capable of targeting the ectoplasmic and transmembrane domains of non-lysosomal proteins to the lysosome (27-29). Lysosomal sorting information is therefore contained within the short cytoplasmic tails (LAMPs: 11 amino acids; LAP: 22 aa; LIMP II: $20 \mathrm{aa})$ of these proteins.

For a number of cell surface receptors (LDL, transferrin, M6P, poly Ig) plasma membrane endocytosis is mediated by a tyrosine-containing internalization signal in the cytoplasmic domain (30-33). Similarly, cytoplasmic motifs, exhibiting differential overlap with the endocytic signal, have been identified which target proteins to the basolateral surface of polarized epi-
ンパク質は、LAMPs(リソソーム膜結合性タンパク質)、 $\operatorname{lgps}($ リ ソソーム糖タンパク質)、LEP(リソソーム、エンドソームタンパ ク質)、LIMP III(リソソーム膜貫通タンパク質)などと呼ばれて いる100-120 kDaの高度にグリコシル化された膜貫通タンパク質 である(総説2、8)。LAMP-1とLAMP-2のようなLAMPsの2つの 種類の相同ファミリーは、約 $20 \%$ のアラ酸相同性があるほ か、11アミノ酸残基の短い細胞質内テイル、膜貫通ドメイン、 そしてプロリンに富むヒンジ領域により分けられる2つの内部的 に相同なドメインを持つ細胞外ドメインなどの構造的に類似し た特徴を示す。LAMP-1とLAMP-2は、2つのタンパク質のすべ てのシステイン残基の保存や、15-18個の $\mathrm{N}$-結合グリコシル化領 域の大部分、および短い細胞質内ドメインに保存されたグリシ ン-チロシンモチーフの存在などの相同性がある(9-18)。他の低 分子量リソソームタンパク質も同定されている(19、20)。LIMP $\mathrm{II}(74 \mathrm{kDa})$ とlgp85は配列が相同であり、N末端の短い細胞質内テ イルと大きな内腔内ドメインがある。内腔内ドメインには、切 断されていないシグナルペプチドと膜にタンパク質を固定する のに役立つと思われるC末端近くの2つの疎水性ドメインがあ る。またおもしろいことに、内腔内ドメインは細胞膜の細胞接 着タンパク質CD63と相同性がある(21、22)。CD63は、4つの疎 水性領域と、3つのN-型糖鎖結合領域、そしてグリシン-チロシ ンモチーフを含む短い細胞質ドメインを持つ。興味深いこと に、このリソソームタンパク質はメラノーマ細胞表面の抗原、 ME491(23、24) と完全な配列の相同性を示す。

\section{M6P以外のリソソーム選別シグナル}

広範にわたるグリコシル化にもかかわらず、これらの様々 なリソソーム膜タンパク質には、トランスゴルジネットワーク (TGN)において可溶なリソソーム加水分解酵素をリソソームへ 選別する役割を持つM6P残基が存在しない(5、17、20、25、 26)。LAMP-1、LAMP-2、そしてLIMP Iは、膜貫通タンパク質 であり、一方LAPは膜貫通タンパク質として合成されリソソー ムへ到達すると加水分解によって開裂し可溶な酵素を遊離す る。キメラタンパク質を用いることで、LAP、LEP100(鳥類の LAMP-1)そしてLIMPIIの細胞質内ドメインが、非リソソーム夕 ンパク質の細胞外、膜貫通ドメインをリソソームへ送達できる ことがわかった(27-29)。リソソームへの選別の情報は、それゆ えこれらのタンパク質の短い細胞質内テイル(LAMPs:11アミ) 酸残基; LAP: 22 アミノ酸残基; LIMP: 20 アミノ酸残基)の中に含 まれていることが分った。

多くの細胞表面レセプター(LDL、トランスフェリン、 M6P、ポリIg)ではエンドサイトーシスは、細胞質内ドメイン中 のチロシンを含む内在化シグナルによって仲介される(30-33)。 同様に、内在化シグナルとかなりの重複を示す細胞質内モチー フは、分極した上皮細胞の基底・側方表面にタンパク質を送達 
thelial cells (34-39). LAMP-1, LAMP-2, LAP and CD63 all contain a tyrosine residue adjacent to a glycine within their cytoplasmic tails. In the case of human LAMP-1, removal of this tyrosine residue results in its surface expression and absence of targeting to lysosomes identifying this single cytoplasmic amino acid as crucial to the sorting of LAMP-1 to the lysosome (40). Similar results were obtained following transfection of selectively mutated lgp120 (rat LAMP-1) into polarized MDCK epithelial cells. Replacement of the cytoplasmic tyrosine resulted not only in surface expression but also a reversal of its polarity from basolateral to apical while removal of the glycine residue adjacent to the tyrosine did not affect its basolateral polarity but decreased the efficiency of its internalization and delivery to lysosomes (37). In a similar fashion removal of the tyrosine residue in the cytoplasmic tail of LAP prevented its lysosomal targeting resulting in its cell surface expression (27). Removal of any of the 6 amino acids (PGYRHV) surrounding the crucial tyrosine, including the adjacent glycine, resulted in significant decreases in its internalization rate (41). A peptide corresponding to the PPGY sequence found in the LAP cytoplasmic domain forms a wellordered $\beta$-turn in solution, as found for similar sequences responsible for plasma membrane internalization (42-44).

For the internalization signals of the M6P, Tf, and polyIg receptors, as well as LAP and LAMPs, the cytoplasmic tyrosine residue is always located 3 amino acids upstream from a hydrophobic amino acid. Removal or replacement of the valine 3 amino acids downstream from the cytoplasmic tyrosine by a non-hydrophobic amino acid blocked internalization of LAP (41). In the case of the M6P-R, it has been shown that the 3 amino acid spacing is crucial for function of the internalization signal (45). For mouse LAMP-1, the Tyr-X-X-hydrophobic amino acid motif functioned as a lysosomal targeting signal only when situated at the end of a short cytoplasmic tail but not internally or at the end of a long cytoplasmic tail (46). In the absence of the terminal isoleucine or other hydrophobic amino acid at the end of the short mouse LAMP-1 cytoplasmic tail, the Gly-Tyr motif is therefore not sufficient for lysosomal targeting. While the LAP lysosomal targeting signal is situated internally, truncation of the cytoplasmic tail just after the hydrophobic valine residue resulted in a significantly increased rate of internalization (41). This cytoplasmic signaling motif has been shown to interact with cellular receptors or adaptins both in the TGN and at the plasma membrane (47). Modulation of this tyrosine-containing targeting signal in different proteins may regulate its interaction with adaptins at different intracellular sites and mediate its specificity and efficiency in plasma membrane internalization, basolateral sorting in polarized epithelia, and lysosomal targeting.

The amino acid sequence of LIMP II has revealed that although its cytoplasmic tail is responsible for targeting to lyso-
することが確かめられた(34-39)。LAMP-1、LAMP-2、LAP、そ してCD63はすべて細胞質内テイル内のグリシン近くにチロシン 残基を含んている。ヒトのLAMP-1の場合、このチロシン残基 を除去すると、表面への発現が起こりリソソームへの送達が消 失する。つまり、リソソームへのLAMP-1の選別に、この一つ の細胞質内アミノ酸が重要であることを明らかにしている (40)。同様の結果が、選択的に変異させたlgp120(ラットLAMP1)を分極したMDCK上皮細胞にトランスフェクションすること により得られた。細胞質内チロシンの置換は、細胞表面への発 現をもたらすだけでなく、その基底・側面送達から頂面送達へ と分極性を逆転してしまう。一方、チロシン近くのグリシン残 基の除去は、基底・側面極性に影響を及ほさないが、その内在 化能力とリソソームへの運搬効率を減少させた(37)。同じよう にLAPの細胞質内テイルのチロシン残基の除去は、リソソーム 送達を妨げ、細胞表面に発現させた(27)。選別シグナルに不可 欠なチロシン近辺の6アミノ酸残基(PGYRHV)のいづれかを除去 すると、内在化速度にかなりの減少をもたらす(41)。LAPの細 胞質内ドメインで見つかったPPGY配列のペプチドは、細胞膜 の内在化に関わる同様の配列で観察されたように、溶液中で秩 序だった $\beta$ ターンを形成している(42-44)。

LAPとLAMPsと同様に、M6P、Tf、そしてポリIgレセプ ターの内在化シグナルでは、細胞質内チロシン残基は、いつも 疎水性アミノ酸残基加 3 アミノ酸残基上流に位置している。細 胞質内チロシンから3アミノ酸残基下流のバリンの除去、あるい は非疎水性アミノ酸残基への置換は、LAPの内在化を妨げた (41)。M6P-Rにおいては、この3アミノ酸残基分の間隔は、内在 化シグナルの機能にとって極めて重要であることが示されてい る(45)。マウスLAMP-1の、チロシン-X-X-疎水性アミノ酸残基 モチーフは、それが短い細胞質内テイルの末端に位置している ときにだけリソソーム送達シグナルとして機能し、内部か、あ るいは長い細胞質内テイルの末端に位置しているときにはリソ ソーム送達シグナルとして機能しなかった(46)。マウスLAMP-1 の短い細胞質内テイルの末端のイソロイシンあるいは他の疎水 性アミノ酸残基が欠如すると、グリシン-チロシンモチーフはリ ソソーム送達に有効でなくなる。LAPのリソソーム送達シグナ ルは、内部に位置しているが、疎水性バリン残基以降の細胞質 内テイルの先端切除により、かなりの内在化速度の増加をもた らした(41)。この細胞質内のシグナルモチーフは、TGNと細胞 膜の両方で細胞のレセプター、あるいはアダプチンと相互作用 することが見い出されている(47)。異なるタンパク質において も、このチロシンを含む送達シグナルの変換は、異なる細胞内 の部位でアダプチンとの相互作用を変化させるかもしれない し、また、細胞膜の内在化、分極した上皮細胞での基底・側面 への選別、そしてリソソームへの送達における特異性や効率を 変えるかもしれない。

LIMP IIにおいては、その細胞質内テイルがリソソームへ の送達の原因となっているにも関わらず、そのアミノ酸配列中 
somes, it does not contain a tyrosine residue $(21,28)$. This suggests that the 20 amino acid cytoplasmic tail of LIMP II contains a lysosomal targeting signal distinct from that of the tyrosine containing motif found in the cytoplasmic tails of LAP and LAMP-1 which may reflect a differential lysosomal targeting pathway for this protein.

\section{The Targeting Pathway of Lysosomal Membrane Glyco- proteins}

The expression of lysosomal membrane proteins on the plasma membrane and whether these proteins traverse the cell surface en route to lysosomes has been a subject of controversy (2). In the case of both LAP and LAMPs, the inability to detect these proteins on the cell surface and their rapid delivery to the lysosome led to the conclusion that they were targeted to the lysosome via an intracellular route $(2,25,48-50)$. However, other studies have suggested that the biosynthetic pathway of LAP, LAMP-1 and LAMP-2 includes the plasma membrane $(29,51,52)$. This review will discuss these findings and their implications for lysosomal sorting.

\section{D-1. Lysosomal Acid Phosphatase}

Lysosomal acid phosphatase is synthesized as a membrane-associated precursor form which upon complex glycosylation is converted to a $67 \mathrm{kDa}$ glycoprotein. Arrival of this integral membrane glycoprotein to lysosomes is first detected one hr after biosynthesis. Following its arrival to the lysosome it is proteolytically cleaved sequentially by a thiol protease at the outside of the lysosomal membrane to remove the cytoplasmic tail and then by an aspartyl protease within the lumen close to the membrane to release the soluble enzyme. This $48 \mathrm{kDa}$ proteolytic fragment is detected in the lysosomal fraction and its appearance is delayed relative to the membrane bound form demonstrating that LAP is targeted to the lysosome as a membrane bound protein (5-7).

Targeting experiments in LAP transfected BHK cells were able to demonstrate that newly synthesized LAP traverses the cell surface prior to delivery to lysosomes $(51)$. At $4^{\circ} \mathrm{C}$, $10-15 \%$ of ${ }^{35} \mathrm{~S}$-methionine pulse labeled LAP was accessible to externally added neuraminidase or anti-LAP antibodies while neuraminidase treatment at $37^{\circ} \mathrm{C}$ was capable of desialylating upwards of $90 \%$ of the protein. Two cycles of neuraminidase treatment at $4^{\circ} \mathrm{C}$ and cell warming to $37^{\circ} \mathrm{C}$ for only $2.5 \mathrm{~min}$ were capable of desialylating $50 \%$ of LAP demonstrating that desialylation occurs at the cell surface and not by neuraminidase taken to endocytic compartments by fluid phase. Similar results were obtained by warming the cells to $20^{\circ} \mathrm{C}$ but not at temperatures below $20^{\circ} \mathrm{C}$ indicating that recycling is occurring from an early endocytic compartment. The cell surface recycling time of LAP in BHK cells is certainly less than 20 min and perhaps as rapid as $6 \mathrm{~min}$. Considering that the delivery of LAP to lysosomes in BHK cells requires 5-6 hrs individual
にはチロシン残基がないことが明らかになっている(21、28)。 これは、LIMP IIの20アミノ酸残基からなる細胞質内テイルが、 LAPとLAMP-1の細胞質内テイルでみつかったチロシンを含む モチーフのリソソーム送達シグナルとは、異なったシグナルを もつことを示しており、そして、それはこのタンパク質にとっ て異なるリソソーム送達経路が存在することを意味する。

\section{D. リソソーム膜糖タンパク質の送達経路}

細胞膜上でのリソソーム膜タンパク質の発現、そして、リ ソソームへ運ばれる経路においてこれらのタンパク質が細胞表 面を経由するかどうかは、議論の的となっているところである (2)。LAPやLAMPsの場合、細胞表面にこれらのタンパク質を見 い出せず、またリソソームへ迅速に運搬されることにより、細 胞内の経路を経てリソソームへ送達されるという結論が導かれ る(2、25、48-50)。しかしながら、他の研究では、LAP、 LAMP-1、そしてLAMP-2の生合成経路に、細胞膜が関わるとい うことが示されている(29、51、52)。この総説では、リソソー ム選別に対するこれらの発見や考察について論じ。

D-1. リソソーム酸性ホスファターゼ

リソソーム酸性ホスファターゼは、膜結合性の前駆体とし て合成され、複雑なグリコシル化によって $67 \mathrm{kDa}$ の糖タンパク 質に転換される。この膜貫通糖タンパク質のリソソームへの到 達は、生合成後1時間で初めて検出される。リソソームへの到達 に続き、リソソーム膜の外側でチオールプロテアーゼにより加 水分解的切断をうけ細胞質内テイルが除去され、そしてその 後、膜に近い内腔内でアスパルチルプロテアーゼによって切断 され、可溶な酵素が遊離される。この $48 \mathrm{kDa}$ の加水分解断片 は、リソソーム分画より検出される。その出現は、膜結合型に 比べ比較的遅く、よってLAPが膜結合性タンパク質としてリソ ソームに送達されるということが示された(5-7)。

LAPをトランスフェクトしたBHK細胞での送達実験におい ては、新たに合成されたLAPが、リソソームへ運搬される前に

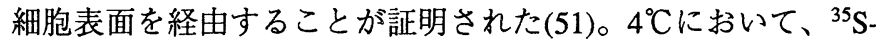
メチオニンでパルスラベルしたLAPの10-15\%が、外部に加えら れたノイラミニダーゼ、あるいは抗LAP抗体の影響を受け、一 方、 $37^{\circ} \mathrm{C}$ でのイラミニダーゼ処理では、タンパク質の $90 \%$ 以

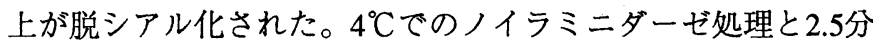
だけの $37^{\circ} \mathrm{C}$ で細胞保温の2回の繰り返しによっては、LAPの50 \%が脱シアル化された。このことは、脱シアル化が、液相から エンドサイトーシス小胞にとりこまれたノイラミニダーゼに よってではなく、細胞表面で起こることを証明している。類似 した結果が $20^{\circ} \mathrm{C}$ 以下ではな $200^{\circ} \mathrm{C}$ に細胞を保温することによっ て得られ、このことから、リサイクリングは初期のエンドサイ トーシス小胞から起っているということがわかる。BHK細胞の LAPの細胞表面リサイクリング時間は、確実に20分より短く、 おそらく6分程度の速さである。BHK細胞でのリソソームへの 
LAP molecules may recycle to the plasma membrane of BHK cells 15-60 times before delivery to lysosomes. These studies were performed in BHK cells expressing $\sim 600$ fold more LAP than endogenous levels. No changes in cell surface expression of LAP were detected by immunogold electron microscopy in cells expressing from 10-600 fold endogenous LAP levels suggesting that surface expression is not due to overexpression of LAP by transfection and saturation of cellular sorting mechanisms (51).

In rat liver, following fluid phase uptake of horseradish peroxidase (HRP) for $10 \mathrm{~min}$, newly synthesized LAP can be selectively precipitated by formation of dense HRP reaction products indicating that the biosynthetic route of LAP traverses the early endosome (53). However, in rat hepatocytes no cell surface LAP expression could be detected by immunogold labeling or in plasma membrane fractions isolated from rat liver (49). Furthermore, no uptake of ${ }^{125}$ I-labeled anti-LAP antibodies by rat hepatocytes could be detected. Control experiments using an antibody against another lysosomal protein, lgp107, which exhibits sequence homology to lgp120 (rat LAMP-1), and whose surface expression has also been a subject of controversy (see below), were able to demonstrate its surface expression $(49,54)$.

The delivery of LAP to dense lysosomes in rat liver has been reported to be as fast as $30 \mathrm{~min}$ and completed within three hrs (7). In transfected BHK cells the delivery of LAP to dense lysosomes is slower with a half-time of approximately 6-7 hrs (6). Nevertheless, considering the rapid rate of internalization of LAP from the plasma membrane an increased rate of delivery of LAP to the lysosome is not sufficient to exclude surface passage. A more rapid delivery to the lysosome would result in a decreased residence time on the cell surface such that the surface detection techniques used may not be sufficiently sensitive to detect the smaller, relative to BHK cells, endogenous steady state levels of LAP on the cell surface of rat hepatocytes. Intrinsically, the targeting pathway of LAP, and other proteins, must be directed by signals present within its amino acid sequence and should therefore be conserved between different cell types. However, expression of receptors for these targeting signals, such as adaptins (47), may be differentially regulated in different cells. Such signals may regulate both endocytosis at the plasma membrane and endosome to lysosome targeting. It is certainly conceivable that different receptor levels in different cell types will result in differential rates of internalization, recycling to the cell surface and lysosomal sorting determining not only the efficiency of lysosomal targeting but also the extent of cell surface appearance of newly synthesized protein.

D-2. Lysosomal Associated Membrane Glycoproteins (LAMPs)

Although the structure and the sequence of LAMPs in a
LAPの運搬には5-6時間を必要とされることから、個々のLAP分 子は、リソソームへの運搬前に15-60回BHK細胞の細胞膜ヘリサ イクルするかもしれない。これらの研究は、内在性のレベルよ り約600倍多くのLAPを発現しているBHK細胞で行われた。内 在性LAPレベルの10-600倍LAPを発現している細胞でもLAPの 細胞表面発現が変化しないことが、金免疫電子顕微鏡により確 かめられた。このことは、表面発現はトランスフェクションに よるLAPの過㮃発現や細胞選別機構の飽和に依るものでないこ とを示唆している(51)。

ラットの肝臓においては、10分間ホースラディシュペルオ キシターゼ(HRP)の液相取り込みに続き、新たに合成された LAPは、濃厚なHRP反応産物の形成によって選択的に沈殿し た。よって、LAPの生合成経路は、初期のエンドソームを経由 するということが示された(53)。しかしながら、ラットの肝細 胞では細胞表面LAPの発現は金免疫ラベルで検出されず、また ラット肝臓から分離された細胞膜分画でも検出されなかった (49)。さらに、125I-ラベルした抗LAP抗体のラットの肝細胞によ る取り込みも検出されなかった。別のリソソームタンパク質 lgp107に対する抗体を用いたコントロール実験では、その表面 発現を証明することができた。 lgp107はlgp120(ラットLAMP-1) に相同した配列を示し、その表面発現もまた論議の的となって いた(49、54)。

ラット肝藏における高密度なリソソームへのLAPの運搬 は、30分程の時間でおこなわれ3時間以内に完結することが報告 されている(7)。トランスフェクトしたBHK細胞における高密度 なリソソームへのLAPの運搬は、およそ6-7時間の半隇期であ り、より遅い(6)。それにもかかわらず、細胞膜からのLAP内在 化の迅速な速度を考えると、リソソームへのLAP運搬の速度増 加を、表面輸送を排除して説明するには不十分である。より迅 速なリソソームへのLAPの運搬は、細胞表面での滞在時間を減 少させる。したがって、BHK細胞に比べてより少ないラット肝 細胞表面上LAPの定常的なレベルを検出するには、今迄の表面 検出技術では感度が不十分かもしれない。本質的に、LAPや他 のタンパク質の送達経路は、そのアミノ酸配列の中に存在する シグナルによって指示され、また、それゅえそれらは異なる細 胞種間でも保持されるべきだろう。しかしながら、アダプチン (47)のようなこれらの送達シグナルに対するレセプターの発現 は、異なる細胞で個々に調整されているのかもしれない。その ようなシグナルは、エンドサイトーシスやリソソームへのエン ドソームの送達の双方を調整しているのかもしれない。異なる 細胞種での異なるレセプターレベルは、内在化速度、細胞表面 へのリサイクリングそしてリソソーム送達に影響し、リソソー ム送達の効率だけでなく新たに合成されたタンパク質の細胞表 面への出現の程度も決定していると考えられる。

\section{D-2．膜結合性リソンーム糖タンパク質(LAMPs)}

様々な種において、LAMPsの構造と配列は高度に保存され ていることがわかっているが、その機能は知られていない(2、 
variety of species has been shown to be highly conserved, the function of the proteins is not known $(2,8)$. Their extensive glycosylation certainly serves to protect the protein from proteolytic degradation from lysosomal proteases (20). Considering the extensive expression of these proteins within the lysosome, they might serve to form a glycocalyx which protects the lysosomal membrane from both proteolysis and the acidic $\mathrm{pH}$ of the intralysosomal lumen $(2,8,17)$. In some immunoelectron microscopy studies, LAMPs were localized predominantly to lysosomes and were not detectable on the plasma membrane $(19,20,55)$ although other studies were able to detect LAMP-1 in the plasma membrane and within endosomal structures (26, 54). Studies of LEP100, avian LAMP-1, in chick fibroblasts demonstrated that it could recycle between the cell surface, endosomes and lysosomes $(26,56)$. Although only $2 \%$ of total cellular LEP100 was expressed on the cell surface at any one time, the half-time of its residence on the cell surface was only 2 min suggesting that the low levels of steady state cell surface expression may not reflect the extent of LEP100 which is actually expressed on the cell surface, even if only transiently (56). Recently, the cumulative reports of the cell surface expression of LAMPs in a variety of cell types in culture have demonstrated unequivocably that LAMPs can be expressed on the cell surface $(26,50,52,54,56-61)$.

In cultured cells, LAMPs are delivered to lysosomes with a half-time of approximately $60 \mathrm{~min}(20,25,26,48)$. Considering that plasma membrane proteins were transported through the Golgi apparatus at similar rates and that the rate of delivery of plasma membrane proteins to the cell surface and of LAMPs to lysosomes were similar, it was concluded that LAMPs must be diverted from the cell surface targeting pathway of plasma membrane proteins at an intracellular post-Golgi site $(25,48)$. The inability to detect LAMPs in early endosomes labeled by Semliki virus was interpreted to mean that LAMPs are sorted to the lysosome in the TGN (48). Similar conclusions were recently reached using $\mathrm{CHO}$ cells transfected with lgp120 mutated in the Gly-Tyr lysosomal targeting signal $(37,50)$. Cell surface expression of low expressing transfectants of $\operatorname{lgp} 120$ was low or undetectable compared to that of high expressing clones or of clones transfected with mutants lacking either the cytoplasmic glycine or tyrosine responsible for lysosomal targeting. Cell surface expression of the high expressing clones was attributed to saturation of an intracellular sorting event and of the mutated proteins to altered recognition of the lysosomal targeting signal. The increased surface expression of the lgp120 glycine mutant could not be attributed to a slower removal from the cell surface as it exhibited an identical internalization rate to normal lgp120. Most significantly, overexpression of lgp120 resulted in the surface expression of an endogenous CHO LAMP-2 strongly indicating that cell surface expression of newly synthesized LAMPs is
8)。それらは、広範なグリコシル化により、リソソームプロテ アーゼによるタンパク質分解から確実に保護されている(20)。 これらのタンパク質がリソソーム内に広範に発現していること を考えると、タンパク質分解とリソソーム内内腔の酸性 $\mathrm{pH} ら$ リソソーム膜を保護する糖衣を形成しているのかもしれない (2、8、17)。免疫電子顕微鏡によるある研究においては、 LAMPsは主にリソソームに局在化し細胞膜上では検出されない (19、20、55)。しかし、他の研究では細胞膜やエンドソーム構 造内にLAMP-1が検出された(26、54)。ヒヨコの繊維芽細胞の LEP100(鳥類のLAMP-1)の研究では、それが細胞表面、エンド ソームそしてリソソームの間でリサイクルすることが示された (25、56)。細胞内の全てのLEP100の2\%だけが、常に細胞表面 に発現しているけれども、細胞表面のその滞在半隇期は約 2 分で ある。このことから、定常状態で細胞表面への発現が低レベル なことが、たとえ一時的であっても実際に細胞表面に発現する LEP100の量を反映してはいないことがわかる(56)。最近、様々 な培養細胞種による多くの報告により、LAMPsは細胞表面に 発現されるということが明確に証明された(26、50、52、54、 56-61)。

培養細胞においては、LAMPSは約60分の半減期でリソソー ムに運搬される(20、25、26、48)。細胞膜タンパク質が同様な 速度でゴルジ体を通り輸送され、また細胞表面への細胞膜タン パク質の速度とリソソームへのLAMPsの運搬速度が同程度であ るということを考えると、LAMPsは細胞内のゴルジ体以降の部 位で、細胞膜タンパク質の細胞表面送達経路からそれると結論 づけられる(25、48)。Semlikiウイルスによってラベルされた初期 のエンドソームでLAMPsを検出できないことは、LAMPsが TGNでリソソームに選別されるということを示している(48)。 同様な結論が最近、グリシン-チロシンリソソーム送達シグナル

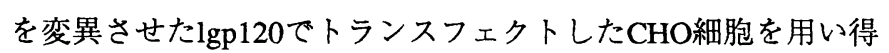
られた(37、50)。 $\operatorname{lgp} 120 を$ 低く発現したトランスフェクタント の細胞表面発現は、高発現クローン、あるいはリソソーム送達 をもたらす細胞質内グリシンかチロシンを欠如した変異体と一 緒にトランスフェクしたクローンに比べ、低いかあるいは検出 不能であった。高発現クローンの細胞表面発現は、細胞内選別 経路の飽和やリソソーム送達シグナルの認識を変化させるほど の変異タンパク質の飽和に起因している。 $\operatorname{lgp} 120$ グリシン変異 体は、正常な $\operatorname{lgp} 120$ と同じ内在化速度を示したので、表面発現 の増加は、細胞表面からのより遅い排除に起因するものではな かった。最も重要なのは、 lgp120の過㮃発現が内在性のCHO LAMP-2の表面発現を増強し、このことは、新たに合成された LAMPsの細胞表面発現が、細胞内選別の飽和の結果であること 
the result of the saturation of an intracellular sorting event. Based on these data it was proposed that surface transit is not necessary for lysosomal targeting of LAMPs and that LAMPs are sorted to the lysosome within an intracellular compartment, likely the TGN (50).

Other studies in different cell systems have indicated that LAMPs are not sorted to a prelysosome or lysosome within the TGN but rather targeted from the TGN to the cell surface or early endosome prior to delivery to the lysosome via the endocytic pathway. In polarized Madin-Darby canine kidney (MDCK) epithelial cells, the biosynthetic targeting pathway of an endogenous LAMP-2 was studied using a surface immunoprecipitation technique at $37^{\circ} \mathrm{C}(52)$. Newly synthesized LAMP-2 could only be detected by antibody added to the basolateral cell surface. Its rate of delivery to the basolateral domain $\left(\mathrm{t}_{1 / 2}=35 \mathrm{~min}\right.$ ) was consistent with a rapid delivery to the lysosome (52). Recent data suggests that the rate of basolateral delivery can be even more rapid $\left(t_{1 / 2}=28 \mathrm{~min}\right)(62)$ such that the rate of surface delivery cannot be considered a limiting factor in the rate of lysosomal delivery of LAMPs. $70 \%$ of newly synthesized LAMP- 2 could be detected by basolateral surface immunoprecipitation demonstrating that basolateral transit is the major biosynthetic route of LAMP-2 to the lysosome in MDCK cells. Addition of antibody at $37^{\circ} \mathrm{C}$ allows the possibility that the antibody is entering the cell by fluid phase and interacting with LAMP-2 within intracellular endocytic compartments. However, in polarized MDCK epithelial cells fluid phase uptake from the apical and basolateral surfaces meet after $15 \mathrm{~min}$ in the prelysosome or late endosome (63). Selective basolateral detection of LAMP-2 by surface immunoprecipitation at $37^{\circ} \mathrm{C}$ indicates that anti-LAMP-2 antibody is encountering LAMP-2 either on the basolateral cell surface or in the early endosome but not deeper within the endocytic pathway. In polarized MDCK epithelial cells, LAMP-2 is therefore targeted to the lysosome via the basolateral cell surface or early endosome and not sorted directly from the TGN to the prelysosome.

Using a vaccinia expression system, a wave of cell surface passage of a chimeric protein containing the transmembrane and cytoplasmic domains of LEP100 and the ectodomain of VSV G coat protein could be detected $1 \mathrm{hr}$ after cycloheximide treatment which disappeared from the cell surface after 2 hrs and accumulated in lysosomes (29). Degradation of the protease sensitive $G$ protein ectodomain occurred within 60 min, a time consistent with the time of delivery of LAMPs to lysosomes. Treatment with the protease inhibitor leupeptin significantly increased the total number of LEP100 molecules detectable within the cell but did not affect those detectable on the cell surface, a result consistent with the position of the plasma membrane prior to the lysosome in the biosynthetic pathway of LAMPs. Furthermore, in the presence of leupeptin
を強く示唆するということである。これらのデータから、表 面輸送は、LAMPsのリソソーム送達に必要ではなく、また LAMPsはTGNのような細胞内胞でリソソームへ選別されるこ とが提案される $(50)$ 。

異なる細胞系での研究から、LAMPsはTGN以前にはプレ リソソームやリソソームには選別されず、むしろTGNから細胞 表面、または内在化経路を経たリソソームへの運搬の前に初期 エンドソームへ選別されることが分った。Madin Darbyイヌ腎臓 (MDCK)の分極した上皮細胞において、内在性のLAMP-2の生合 成送達経路が、 $37^{\circ} \mathrm{C} て ゙$ 表面免疫沈降法を用い研究された(52)。 新たに合成されたLAMP-2は、細胞の基底・側面に加えられた 抗体によってのみ検出された。基底・側面部分への運搬速度 $\left(\mathrm{t}_{1 /}\right.$ $\left.{ }_{2}=35 \mathrm{~min}\right)$ は、リソソームへの迅速な運搬速度と一致していた (52)。最近のデータによると、基底・側面への運搬速度 $\left(\mathrm{t}_{1 / 2}=28\right.$ $\min )(62)$ は早く、従って、表面への運搬速度によって、LAMPs のリソソームへの運搬速度を限定することはできない。新たに 合成されたLAMP-2の70\%は、基底・側面での免疫沈降により 検出され、このことから、MDCK細胞で、基底・側面輸送がリ ソソームへのLAMP-2の主な生合成経路であることが証明され

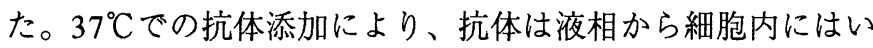
り、細胞内エンドサイトーシス小胞でLAMP-2と相互作用して いる可能性が認められた。しかしながら、分極したMDCK上皮 細胞では、頂面や基底・側面から液相取り込みが起こると、15 分後にはプレリソソームや後期のエンドソームに到る(63)。37 ${ }^{\circ} \mathrm{C}$ 下、表面免疫沈降法による基底・側面でのLAMP-2の選択的 な検出により、抗LAMP-2抗体が内在化経路の後期ではなく、 初期のエンドソーム内あるいは細胞の基底・側面でLAMP-2 出くわしていることが示された。それゆえ分極したMDCK上皮 細胞では、LAMP-2は基底・側面の表面や初期のエンドソーム を経てリソソームへ運搬されるのであり、TGNからプレリソ ソームへ直接選別されるのではない。

ワクシニア発現系を用いることで、LEP100の膜貫通及び 細胞質内ドメインをもちVSVG外殼タンパク質の細胞外ドメイ ンからなるキメラタンパク質の細胞表面運搬の変動が、シクロ ヘキシイミド処理1時間後に検出され、2時間後には細胞表面か ら消失し、リソソームに蓄積された(29)。プロテアーゼに感受 性のGタンパク質細胞外ドメインの分解は60分以内に起こり、 これはリソソームへのLAMPsの運搬の時間と一致する。プロテ アーゼ阻害剤であるロイペプチンによる処理により、細胞内で 検出されるLEP100の分子総数が顕著に増加したが、細胞表面上 に検出される数には影響を及ほさなかった。この結果はLAMPs の生合成経路においてリソソーム以前に細胞膜が存在すること

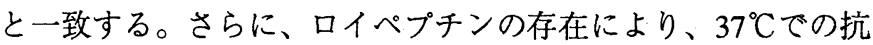


it was quantitatively demonstrated that anti-G protein antibody uptake at $37^{\circ} \mathrm{C}$ was equivalent to the total detectable chimeric protein expressed in the cell. This result was obtained irrelevant of the levels of expression of the chimeric protein suggesting that surface expression was not a consequence of saturation of intracellular sorting receptors. The $4 \%$ of the chimeric molecules which can be detected on the cell surface appear and disappear very rapidly from the cell surface; this is consistent with rapid recycling between a larger endosomal pool of LEP100 and a smaller amount of plasma membrane expressed protein as previously found for endogenous LEP100 in chick fibroblasts $(29,56)$. It was therefore impossible to determine if LEP100 is targeted to the lysosome via the plasma membrane or early endosome. The rapid recycling between the two compartments would suggest that any LEP100 which has arrived to the early endosome would likely also be expressed on the cell surface. As found for LAMP-2 in MDCK cells, LEP100 is not sorted in the TGN to the lysosome.

\section{D-3. LIMP II}

LIMP II was originally shown to be targeted to the lysosome with a half-time of $1 \mathrm{hr}$, consistent with the rate of delivery of LAMPs (20). Transfection studies with cloned LIMP II were unable to detect newly synthesized protein on the cell surface by immunofluorescent staining (28). However, for the reasons discussed above for LAP and LAMPs, these results cannot be interpretated to indicate conclusively that newly synthesized LIMP II does not transiently pass through the cell surface. The fact that the cytoplasmic domain of LIMP II, while capable of targeting the protein to the lysosome, does not contain the tyrosine-containing motif of LAP and LAMPs suggests that LIMP II is targeted to lysosomes using an alternate signaling mechanism and possibly via an alternate pathway.

\section{E. Is the Plasma Membrane a Constitutive Component of the Targeting Pathway of LAP and LAMPs?}

Surface expression of newly synthesized lysosomal membrane proteins en route to the lysosome will necessarily be transient; depending on the rate of plasma membrane transit, steady state surface detection methods will only detect a fraction of the total protein which might have traversed the cell surface. Surface detection techniques utilizing fixed tissue or cells incubated at $4^{\circ} \mathrm{C}$ cannot therefore quantitatively determine the degree of a transient surface passage and negative results using such techniques cannot definitively demonstrate the lack of surface passage. Lack of surface detection might be due to a combination of a highly transient cell surface expression of individual proteins and inefficiency of the labeling techniques used. Quantitative detection of the transient passage of a protein can be performed by the addition of reagents at $37^{\circ} \mathrm{C}$; however at $37^{\circ} \mathrm{C}$ these reagents may not be restricted to the plasma membrane and may reach intracellular compartments
Gタンパク質抗体の取り込みが、細胞内で発現された検出され る全キメラタンパク質と同量であることが定量的に証明され た。この結果は、キメラタンパク質の発現レベルに無関係であ り、よって表面発現が細胞内選別レセプターの飽和の結果では ないといえる。細胞表面に検出されたキメラ分子の $4 \%$ は、細胞 表面から非常に迅速に出現したり、消失したりする。これは、 ヒヨコの纎維芽細胞において内在性のLEP100で先に見られたよ うに、LEP100のより大きなエンドソームのプールとタンパク質 を発現しているより少量の細胞膜との間で迅速にリサイクリン グしている結果と一致している(29、56)。ゆえに、LEP100が細 胞膜あるいは初期エンドソームを経てリソソームに送達される かどうかを決定することは不可能である。2つの部位の間での迅 速なリサイクリングは、初期エンドソームに到達したどんな LEP100も、細胞表面に発現されることを示している。MDCK細 胞のLAMP-2で分ったように、LEP100はリソソームへの過程で TGNには選別されない。

\section{D-3. LIMP II}

LIMP IIは、もともと半隇期1時間でリソソームへ送達され ることが分っており、これはLAMPsの運搬速度と同じである (20)。LIMPIIクローンを用いたトランスフェクションでは、新 たに合成されたタンパク質を、細胞表面に免疫蛍光法によって は検出できなかった(28)。しかしながら、LAPとLAMPsに対し 既に論議したのと同じ理由で、これらの結果が、新たに合成さ れたLIMPIIか、一時的にも細胞表面を通り抜けはしないという ことを決定的に示すとは解釈できない。リソソームへタンパク 質を送達できるにもかかわらず、LIMP IIの細胞質内ドメイン は、LAPやLAMPsのチロシンをもつモチーフを含んでいないと いう事実は、LIMPIIが代わりのシグナル機構を用い、そしてお そらく代わりの経路を経てリソソームへ送達されることを示し ている。

\section{E. 細胞膜はLAPやLAMPsの送達経路の構成要素か?}

リソソームへ導かれる新たに合成されたリソソーム膜タン パク質の表面発現は、細胞膜輸送の速度に依存しており、必ず 一過性なものであろう。定常な状態での表面検出法は、細胞表 面を経由すると思われる全タンパク質の一部を検出するにすぎ

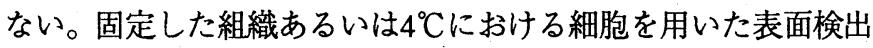
技術では、一過性の表面通過量を定量的に決定できないし、そ のような技術を用いた否定的な結果は、表面通過の欠失を明確 には証明できない。表面検出ができないのは、個々のタンパク 質の細胞表面発現が高度に一過性なことと、用いられたラベル 技術の非効率性の双方によるのかもしれない。タンパク質の一 時的な通過の定量的な検出は、 $37^{\circ} \mathrm{C} て ゙$ 試薬を添加することより 行うことができる。しかしながら、37ㅇではこれらの試薬は細 胞膜上に限定されず、液相取り込みにより細胞内の部位に到達 するかもしれない。そのような技術を用いてLAMPSやLAPの生 
by fluid phase endocytosis. Use of such techniques have provided support for the involvement of the plasma membrane in the biosynthetic pathway of both LAMPs and LAP $(29,51,52)$. Contrary data has indicated that these proteins are not expressed on the cell surface and that they are therefore targeted to the lysosome via an intracellular route $(25,48-50,53)$. In particular, the data of Harter et al. (50) indicates that LAMPs are sorted to the lysosome at an intracellular site.

Localization of this intracellular sorting event to an early endosomal compartment would reconcile the conflicting data (Fig. 1). Newly synthesized lysosomal proteins would be delivered from the Golgi apparatus to the early endosome where they could recycle with the plasma membrane before being sorted via a saturable endosomal sorting event to the lysosome. Such an idea would explain studies of the targeting of LAP which in transfected BHK cells was demonstrated to pass through the cell surface (51), while in rat liver was not detected in the plasma membrane but was shown to pass through an early endosomal compartment $(49,53)$. Newly synthesized lysosomal membrane proteins would be delivered from the TGN to an early endosome or perhaps a sorting endosome (64). In the case of recycling receptors, such as the transferrin, LDL and asialoglycoprotein receptors, sorting of lysosomally targeted ligands from their receptors occurs within an early sorting endosome; the receptor recycles to the cell surface while the ligand is targeted to the lysosome via late endosomes (65-67).
合成経路に細胞膜が関与していることが支持されている(29,51、 52)。これに反して、これらのタンパク質が細胞表面で発現せ ず、細胞内経路を経てリソソームに送達されるということを示 しているデータがある(25、48-50、53)。特に、Harterらのデー 夕(50)ではLAMPsが細胞内部位でリソソームに選別されること を示している。

初期エンドソームがこの細胞内選別部位とすると、矛盾し たデータを解釈できる(図1)。新たに合成されたリソソームタン パク質は、ゴルジ体から初期エンドソームへ運搬され、そこで は簡単に飽和しうるエンドソーム選別過程によりリソソームへ 選別される前に、細胞膜と一緒にリサイクルされうる。ラット の肝臓の細胞膜では検出されず、初期エンドソームを経由する ことが見い出された(51)ものの、そのような考えは、トランス フェクトしたBHK細胞で、細胞表面を経由することが証明され たLAPの送達の研究結果を説明できるであろう (49、53)。新たに 合成されたリソソーム膜タンパク質は、TGNから初期エンド ソームあるいは拀そらく選別エンドソームへ運搬される(64)。 トランスフェリン、LDL、そしてアシアロ糖タンパク質レセプ ターのようなリサイクリングレセプターの場合、レセプターか らのリソソーム送達リガンドの選別は、初期選別エンドソーム 内で起こる。レセプターは細胞表面にリサイクルする一方で、 リガンドは後期エンドソームを経てリソソームに送達される

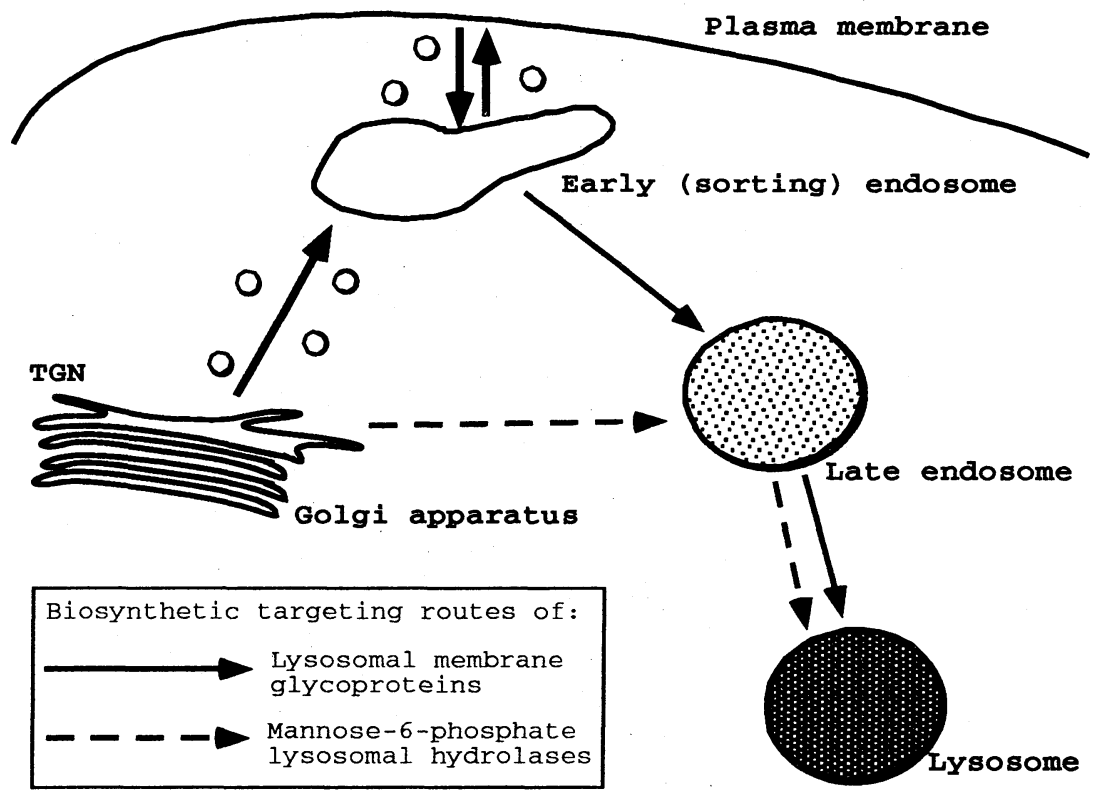

Fig. 1. Biosynthetic lysosomal targeting pathways. Newly synthesized lysosomal membrane glycoproteins are targeted from the Golgi apparatus to an early sorting endosome from which they can recycle to the plasma membrane and from which they are directed via a saturable sorting event to the late endosome and lysosome. Mannose-6-phosphate containing lysosomal hydrolases interact with a mannose-6-phosphate receptor and are sorted within the TGN to a late endosome where they dissociate from the receptor and are delivered to the lysosome as soluble proteins. Such a model describes two distinct lysosomal sorting events in two intracellular organelles, although it should be noted that it is not certain that the mannose-6-phosphate receptor is indeed targeted to the late endosome from the Golgi (3). 
If lysosomal membrane proteins are also sorted to the lysosome within a sorting endosome, the rate of lysosomal targeting would be independent of the rate of plasma membrane internalization but depend rather on the efficiency of a lysosomal sorting event within an endosomal compartment. The presence of a highly efficient endosome to lysosome sorting event in some cell types might result in the targeting of newly synthesized lysosomal proteins to the lysosome without appearance on the cell surface.

The nature of such an endosomal sorting event is unclear. Delivery of newly synthesized lysosomal membrane glycoproteins to the plasma membrane/early endosome compartment would suggest that they are subsequently targeted to the lysosome as are endocytosed plasma membrane receptors, but perhaps in a constitutive manner. Proteins targeted to the lysosome might be segregated from those which recycle to the cell surface by the selective recognition of the lysosomal targeting signal compared to the solely endocytic signal of recycling receptors. The tyrosine-containing cytoplasmic motif of membrane proteins is considered to function as a sorting signal in endocytosis and basolateral sorting due to its recognition by adaptins in either the plasma membrane or the TGN which mediate association with clathrin coated vesicles (47). The cytoplasmic lysosomal targeting motif might therefore also function within the sorting endosome, perhaps through recognition by a specific adaptin-like molecule using mechanisms similar to those mediating endocytosis at the plasma membrane and vesicle budding in the TGN. Lysosomal sorting of endocytosed ligands released from their recycling receptors has been demonstrated to occur via a maturation process $(64,68)$. Following endocytosis, sorting of the lysosomally targeted EGF receptor from the recycling transferrin receptor occurs within a multivesicular body; the EGF receptor is found within internal vesicles while the transferrin receptor remains on the limiting membrane of the multivesicular body (69). Localization of the sorting of lysosomal membrane glycoproteins in the biosynthetic pathway to an early endosomal compartment and the mechanisms underlying such a sorting event remain to be demonstrated.

\section{F. Conclusion}

Lysosomal targeting of LAPs and LAMPs is mediated by a tyrosine containing signal in their cytoplasmic domains similar in many respects to that mediating plasma membrane internalization and basolateral targeting in polarized epithelia for a number of cellular transmembrane proteins. The M6P lysosomal targeting route may be a specialized intracellular sorting mechanism to divert soluble lysosomal hydrolases to the lysosome which would otherwise be secreted. The integral association of lysosomal membrane glycoproteins with cellular membranes would maintain their association with the cell even
(65-67)。もし、リソソーム膜タンパク質もまた選別エンドソー ム内でリソソームに選別されるなら、リソソームへの送達速度 は細胞膜内在化の速度に依存せず、エンドソーム内のリソソー ム選別の効率に依存するだろう。いくつかの細胞種において、 リソソーム選別が高効率であるエンドソームの存在が、新たに 合成されたリソソームタンパク質を細胞表面へ出現させず、リ ソソームへ送達させるのかもしれない。

そのようなエンドソーム選別の性質は、はっきりしていな い。新たに合成されたりソソーム膜糖タンパク質が、細胞膜あ るいは初期エンドソームへ運搬されることから、おそらく、内 在化された細胞膜レセプターのように(但し、それとは異なり絶 えず)リソソームへ送達されることを示している。リサイクリン グレセプターの内在化シグナルと、リソソーム送達シグナルの 選択的認識によって、リソソームへ送達されるタンパク質は細 胞表面にリサイクルするレセプターから区別されるのかもしれ ない。膜タンパク質のチロシンを含む細胞質内モチーフは、エ ンドサイトーシスや基底・側面への選別シグナルとして機能し ていると思われる。その機能は、クラスリン被覆小胞との結合 を媒介するTGNか細胞膜で、アダプチンによって認識されるこ とに起因する。おそらくエンドサイトーシスやTGNでの小胞で の生成と類似した機構で、選別エンドソーム内で特異的なアダ プチン様分子による認識を通し細胞質内リソソーム送達モチー フは機能するのだろう(47)。リサイクリングするレセプターか ら遊離した、内在化されたりガンドのリソソーム選別は、成熟 過程を経て起こることが明らかにされている(64、68)。エンドサ イトーシスに続きリサイクリングするトランスフェリンレセプ ターとリソソームに送達されるEGFレセプターの選別は、多胞 体内で起こる(69)。EGFレセプターは小胞内で見つかり、一方 トランスフェリンレセプターは多胞体の限られた膜上に留まっ ている。生合成経路において、リソソーム膜糖タンパク質の初 期エンドソームへの選別や、そのような選別の基礎をなす機構 が明らかにされずにいる。

\section{F. 結 論}

LAPやLAMPsのリソソーム送達は、細胞質内ドメイン内の チロシンを持つシグナルによって仲介される。そのシグナル は、分極化した上皮細胞での多くの膜貫通タンパク質の細胞膜 内在化や、基底・側面送達を仲介しているシグナルに多くの点 で類似している。M6Pリソソーム送達経路は、もしそれがなけ れば分泌されてしまうような可溶なリソソーム加水分解酵素を リソソームへと運ぶ特殊化された細胞内送達経路である。細胞 膜とリソソーム膜糖タンパク質の内在的な結合で、リソソーム 
Trends in Glycoscience and Glycotechnology

in the absence of a completely intracellular route to the lysosome. Lysosomal membrane glycoproteins such as LAP and LAMPs may thereby be characterized by a biosynthetic targeting route to a plasma membrane/early endosome compartment and a highly efficient endocytic and lysosomal targeting signal in their cytoplasmic domains. It remains to be determined whether other signaling mechanisms and targeting pathways exist to direct lysosomal membrane proteins to the lysosome.

\section{Acknowledgements}

The work of the author is supported by the Medical Research Council of Canada and Cancer Research Society.
への細胞内のみの経路が消失しても細胞との結合が維持できる のであろう。LAPやLAMPsのようなリソソーム膜糖タンパク質 は、細胞膜あるいは初期エンドソームへの生合成送達経路、細 胞質内部位にある高効率の内在化及びリソソーム送達シグナル によって特徴づけられる。リソソームヘリソソーム膜タンパク 質をむかわせる他のシグナル機構や送達経路が存在するかどう かまだ研究が必要である。

\section{東京工業大学・生命理工学部・生体分子工学科}

石原 務訳

\section{References}

1. von Figura, K., and Hasilik, A. (1986) Ann. Rev. Biochem. 55, 167-193

2. Kornfeld, S., and Mellman, I. (1989) Ann. Rev. Cell Biol. 5, 483-525

3. Wendl, and, M. (1992) Trends Glycosci. Glycotechnol. 4, 200-209

4. Pohlmann, R., Krentler, C., Schmidt, B., Schröder, W., Lorkowski, G., Culley, J., Mersmann, G., Geier, C., Waheed, A., Gottshalk, S., Grzeschik, K.-H., Hasilik, A., and von Figura, K. (1988) EMBO J. 7, 1343-2350

5. Waheed, A., Gottshalk, S., Hille, A., Krentler, C., Pohlmann, R., Braulke, T., Hauser, H., Geuze, H., and von Figura, H. (1988) EMBO J. 7, 2351-2358

6. Gottshalk, S., Waheed, A., Schmidt, B., Laidler, P., and von Figura, K. (1989) EMBO J. 8, 3215-3219

7. Tanaka, Y., Harada, R., Himeno, M., and Kato, K. (1990) J. Biochem. 108, 278-286

8. Fukuda, M. (1991) J. Biol. Chem. 266, 21327-21330

9. Howe, C.L., Granger, B. L., Hull, M., Green, S.A., Gabel, C.A., Helenius, A. , and Mellman, I. (1988) Proc. Natl. Acad. Sci. USA. 85, 75777581

10. Fambrough, D.M., Takeyasu, K., Lippincott-Schwartz, J., and Siegel, N.R. (1988) J. Cell Biol. 106, 61-67

11. Chen, J.W., Cha, Y., Yuksel, K.U., Gracy, R.W., and August, J.T. (1988) J. Biol. Chem. 263, 8754-8758

12. Viitala, J., Carlsson, S.R., Siebert, P.D., and Fukuda, M. (1988) Proc. Natl. Acad. Sci. U.S.A. 85, 3743-3747

13. Fukuda, M., Viitala, J., Matteson, J.., and Carlsson, S.R. (1988) J. Biol. Chem. 263, 18920-18928

14. Carlsson, S.R. , and Fukuda, M. (1989) J. Biol. Chem. 264, 20526-20531

15. Himeno, M., Noguchi, Y., Sasaki, H., Tanaka, Y., Furuno, K., Kono, A., Sakaki, Y., and Kato, K. (1989) FEBS Lett. 244, 351-356

16. Noguchi, Y., Himeno, M., Sasaki, H., Tanaka, Y., Kono, A., Sakaki, Y., and Kato, K. (1989) Biochem. Biophys. Res. Comm. 164, $1113-1120$

17. Granger, B.L., Green, S.A., Gabel, C.A., Howe, C.L., Mellman, I. , and Helenius, A. (1990) J. Biol. Chem. 265, 12036-12043

18. Cha, Y., Holl, and, S.M., and August, J.T. (1990) J. Biol. Chem. 265, 5008-5013

19. Lewis, V., Green, S.A., Marsh, M., Vihko, P., Helenius, A., and Mellman, I. (1985) J. Cell Biol. 100, 1839-1847

20. Barriocanal, J.G., Bonifacino, J.S., Yuan, L., and Sandoval, I.V. (1986) J. Biol. Chem. 261, 16755-16763

21. Vega, M.A., Segui-Real, B., Garciá, J.A., Calés, C., Rodriguez, F., Vanderkerckhove, J., and Sandoval, I.V. (1991) J. Biol. Chem. 266, 16818-16824

22. Fujita, H., Ezaki, J., Noguchi, Y., Kono, A., Himeno, M., and Kato, K. (1991) Biochem. Biophys. Res. Comm. 178, $444-452$

23. Hotta, H., Ross, A.H., Huebner, K., Isobe, M., Wendeborn, S., Chao, M.V., Ricciardi, R.P., Tsujimoto, Y., Croce, C.M., and Koprowski, H. (1988) Cancer Res. 48, 2955-2962

24. Metzelaar, M.J., Wijngaard, P.L.J., Peters, P.J., Sixma, J.J., Nieuwenhuis, H.K., and Clevers, H.C. (1991) J. Biol. Chem. 266, $3239-3245$

25. D'Souza, M.P., and August, J.T. (1986) Arch. Biochem. Biophys. 249, 522-532

26. Lippincott-Schwartz, J., and Fambrough, D.M. (1986) J. Cell Biol. 102, 1593-1605

27. Peters, C., Braun, M., Weber, B., Wenl, and, M., Schmidt, B., Pohlmann, R., Waheed, A., and von Figura, H. (1990) EMBO J. 9, $3497-3506$

28. Vega, M.A., Rodriguez, F., Segui, B., Calés, C., Alcade, J., and S, andoval, I.V. (1991) J. Biol. Chem. 266, 16269-16272

29. Mathews, P., Martinie, J., and Fambrough, D. (1992) J. Cell Biol. 118, 1027-1040

30. Chen, W.-J., Goldstein, J.L., and Brown, M.S. (1990) J. Biol. Chem. 1990, 3116-3123

31. Jing, S., Spencer, T., Miller, K., Hopkins, C., and Trowbridge, I.S. (1990) J. Cell Biol. 110, 283-294

32. Breitfeld, P.P., Casanova, J.E., McKinnon, W.C., and Mostov, K.E. (1990) J. Biol. Chem. 266, 13750-13757

33. Canfield, W.M., Johnson, K.F., Ye, R.D., Gregory, W., and Kornfeld, S. (1991) J. Biol. Chem. 266, 5682-5688

34. Casanova, J.E., Apodaca, G., and Mostov, K.E. (1991) Cell 66, 65-75

35. Brewer, C., Thomas, D., and Roth, M. (1991) J. Cell Biol. 114, 413-421

36. Le Bivic, A., Sambuy, Y., Patzak, A., Patil, N., Chao, M., and Rodriguez-Boulan, E. (1991) J. Cell Biol. 115, 607-618

37. Hunziker, W., Harter, C., Matter, K., and Mellman, I. (1991) Cell 66, 907-920

38. Yokode, M., Pathak, R.K., Hammer, R.E., Brown, M.S., Goldstein, J.L., and Anderson, R.G.W. (1992) J. Cell Biol. 117, $39-46$

39. Matter, K., Hunziker, W., and Mellman, I. (1992) Cell 71, 741-753

40. Williams, M.A., and Fukuda, M. (1990) J. Cell Biol. 111, 955-966

41. Lehmann, L.E., Eberle, W., Krull, S., Prill, V., Schmidt, B., Sander, C., von Figura, K., and Peters, C. (1992) EMBO J. 11, $4391-4399$

42. Eberle, W., Sander, C., Klaus, W., Schmidt, B., von Figura, K., and Peters, C. (1991) Cell 67, 1203-1209

43. Bansal, A., and Gierasch, L.M. (1991) Cell 67, 1195-1201 
44. Collawn, J.F., Stangel, M., Kuhn, L.A., Esekogwu, V., Jing, S., Trowbridge, I.S., and Tainer, J. (1990) Cell 63, 1061-1072

45. Jadot, M., Canfield, W.M., Gregory, W., and Kornfeld, S. (1992) J. Biol. Chem. 267, 11069-11077

46. Guarnier, F.G., Arterburn, L.M., Penno, M.B., Cha, Y., and August, J.T. (1993) J. Biol. Chem. 268, 1941-1946

47. Pearse, B.M.F., and Robinson, M.S. (1990) Ann. Rev. Cell Biol. 6, 151-171

48. Green, S.A., Zimmer, K.-P., Griffiths, G., and Mellman, I. (1987) J. Cell Biol. 105, 1227-1240

49. Tanaka, Y., Yano, S., Furuno, K., Ishikawa, T., Himeno, M., and Kato, K. (1990) Biochem. Biophys. Res. Comm. 170, 1067-1073

50. Harter, C., and Mellman, I. (1992) J. Cell Biol. 117, 311-325

51. Braun, M., Waheed, A., and von Figura, K. (1989) EMBO J. 8, 3633-3640

52. Nabi, I.R., Le Bivic, A., Fambrough, D., and Rodriguez-Boulan, E. (1991) J. Cell Biol. 115, 1573-1584

53. Tanaka, Y., Yano, S., Okada, K., Ishikawa, T., Himeno, M., and Kato, K. (1990) Biochem. Biophys. Res. Comm. 166, 1176-1182

54. Furuno, K., Ishikawa, T., Akasaki, K., Yano, S., Tanaka, Y., Yamaguchi, Y., Tsuji, H., Himeno, M., and Kato, K. (1989) J. Biochem. 106, 708-716

55. Chen, J.W., Murphy, T.L., Willingham, M.C., Pastan, I., and August, J.T. (1985) J. Cell Biol. 101, 85-95

56. Lippincott-Schwartz, J., and Fambrough, D.M. (1987) Cell 49, 669-677

57. Mane, S., Marzella, L., Bainton, D., Holt, V., Cha, Y., Hildreth, J., and August, J. (1989) Arch. Biochem. Biophys. 268, 360-378

58. Do, K.-Y., Smith, D.F., and Cummings, R.D. (1990) Biochem. Biophys. Res. Comm. 173, 1123-1128

59. Amos, B., and Lotan, R. (1990) J. Biol. Chem. 265, 19192-19198

60. Febbraio, M., and Silverstein, R.L. (1990) J. Biol. Chem. 265, 18531-18537

61. Saitoh, O., Wang, W.-C., Lotan, R., and Fukuda, M. (1992) J. Biol. Chem. 267, 5700-5711

62. Nabi, I. R., and Rodriguez-Boulan, E. (1993) Molec. Biol. Cell 4, 627-635

63. Bomsel, M., Prydz, K., Parton, R.G., Gruenberg, J., and Simons, K. (1989) J. Cell Biol. 109, 3243-3258

64. Dunn, K.W., and Maxfield, F.R. (1992) J. Cell Biol. 117, 301-310

65. Geuze, H.J., Slot, J.W., Strous, G.J., Lodish, H.F., and Schwartz, A.L. (1983) Cell 32, 277-287

66. Griffiths, G., Back, R., and Marsh, M. (1989) J. Cell Biol. 109, 2703-2720

67. Dunn, K.W., McGraw, T.E., and Maxfield, F.R. (1989) J. Cell Biol. 109, 3303-3314

68. Stoorvogel, W., Strous, G.J., Geuze, H.J., Oorschot, V., and Schwartz, A.L. (1991) Cell 65, 417-427

69. Felder, S., Miller, K., Moehren, G., Ullrich, A., Schlessinger, J., and Hopkins, C.R. (1990) Cell 61, 623-634

Received on July 8, 1993, accepted on July 15, 1993 